\title{
GENOTOXICITY OF PLANT EXTRACTS
}

\author{
VERA M. F. VARGAS; RÉGIS R. GUIDOBONO/ ${ }^{+} \&$ JOÃO A. P. HENRIOUES*
}

\begin{abstract}
Departamento do Meio Ambiente, Secretaria da Saúde e Mejo Ambiente, Av. A. J. Renner, 10, 90250 Porto Alegre, RS, Brasil *Departamento de Fisiologia, Farmacologia e Biofísica, Instituto de Biociências, UFRGS, Rua Sarmento Leite, 500, 90049 Porto Alegre, RS, Brasil
\end{abstract}

Aqueous extracts of seven species used in Brazilian popular medicine (Achyrocline satureoides, Iodina rhombifolia, Desmodium incanum, Baccharis anomala, Tibouchina asperior, Luehea diva. ricata, Maytenus ilicifolia) were screened to the presence of mutagenic activity in the Ames test (Salmonella/microsome). Positive results were obtained for A. satureoides, B. anomala and L. divaricata with microsomal activation. As shown elsewhere (Vargas et al., 1990) the metabolites of A. satureoides extract also show the capacity to induce prophage and/or SOS response in microscreen phage induction assay and SOS spot chromotest.

The positive results were related to the presence of flavonoids and tannins in the aqueous extracts.

$$
\begin{gathered}
\text { Key words: Ames test }- \text { flavonoids - tannins - plant extracts - Achyrocline satureoides - } \\
\text { Luehea divaricata - Baccharis anomala }
\end{gathered}
$$

The effect of environmental factors and their role in human mutagenesis/carcinogenesis has been significantly emphasized in the last decade. Epidemiological research has shown significant variations in cancer incidence both between and within countries (Brown, 1980; Ames, 1983).

The human diet contains a great variety of natural mutagens and carcinogens and this is an area deserving careful investigation. In nature plants synthesize toxic chemicals in large amounts, apparently as a primary defense against the horders of bacterial, fungal, insect and other animal predators (Ames, 1983).

Preparations of medicinal plants are widely used in human therapy although little information on their potential risk to health is available.

Aqueous extracts of plants widely used in medicinal practice in Brazil were investigated for the presence of genotoxic activity in micro. organisms.

\section{MATERIAL AND METHODS}

Samples - The plants were collected from unpolluted areas and botanically classified. The

This work was supported by CNPq - FAPERGS FINEP - PIMUT.

${ }^{+}$Research fellow CNPq. dried plant material (Table I) was used to prepare the extracts in boiling water at a concentration of $50 \%$ weight/volume. Samples were sterilized using Sartorius filter with $0,22 \mu \mathrm{m}$ pore size.

Strains - The Salmonella typhimurium strains TA98, TA100 and TA102 were kindly provided by B. M. Ames, University of California, Berkeley, CA, USA.

Salmonella/microsome assay - Mutagenicity was analyzed by the preincubation procedure (Maron \& Ames, 1983). Mutation tests were performed on samples of plant extracts in the presence or absence of $S 9 \operatorname{mix}(20 \mu 1$ of 59 fraction prepared from Sprague-Dawley rat livers pretreated with 3-methylcholanthrene containing $16,3 \mathrm{mg} / \mathrm{ml}$ protein per $500 \mu 1$ of S9 mix). The screening test was performed using TA100 and TA98 strains. In infusions of $A$. satureoides, $B$. anomala and $L$. divaricata the TA102 strain was also used.

\section{RESULTS}

Table II shows the results of mutagenic activity for seven plant extracts screened in the Ames test using TA100 (detects base-pair substitution mutagens) and TA98 (detects frameshift mutagens) strains with and without metabolization. 
TABLE I

Medicinal plants screened for mutagenicity in Ames test

\begin{tabular}{|c|c|c|c|}
\hline Sample & Popular name & Plant part & $\begin{array}{l}\text { Therapeutical use } \\
\text { (Alice et al., 1985) }\end{array}$ \\
\hline $\begin{array}{l}\text { Achyrocline } \\
\text { satureoides } \\
\text { Lam D. C. }\end{array}$ & marcela & flowers & $\begin{array}{l}\text { antispasmodic } \\
\text { analgesic } \\
\text { anti-inflammatory }\end{array}$ \\
\hline $\begin{array}{l}\text { Iodina } \\
\text { rhombifolia } \\
\text { Arn. }\end{array}$ & cancorosa & leaves & $\begin{array}{l}\text { analgesic } \\
\text { antiseptic } \\
\text { cicatrizant }\end{array}$ \\
\hline $\begin{array}{l}\text { Desmodium } \\
\text { incanum } \mathrm{D} . \mathrm{C} .\end{array}$ & $\begin{array}{l}\text { amor do } \\
\text { campo }\end{array}$ & $\begin{array}{l}\text { leaves } \\
\text { stems }\end{array}$ & $\begin{array}{l}\text { diuretic } \\
\text { anti-inflammatory }\end{array}$ \\
\hline $\begin{array}{l}\text { Baccharis } \\
\text { anomala D. C. }\end{array}$ & $\begin{array}{l}\text { uva do } \\
\text { mato }\end{array}$ & $\begin{array}{l}\text { leaves } \\
\text { stems }\end{array}$ & diuretic \\
\hline $\begin{array}{l}\text { Tibouchina } \\
\text { asperior } \\
\text { (CHAM.) Cogn. }\end{array}$ & douradinha & $\begin{array}{l}\text { leaves } \\
\text { stems }\end{array}$ & diuretic \\
\hline $\begin{array}{l}\text { Luehea } \\
\text { divaricata Mart. }\end{array}$ & $\begin{array}{l}\text { açoita } \\
\text { cavalo }\end{array}$ & $\begin{array}{l}\text { leaves } \\
\text { stems }\end{array}$ & $\begin{array}{l}\text { diuretic } \\
\text { anti-inflammatory }\end{array}$ \\
\hline $\begin{array}{l}\text { Maytenus } \\
\text { ilicifolia Mart. }\end{array}$ & $\begin{array}{l}\text { espinheira } \\
\text { santa }\end{array}$ & leaves & $\begin{array}{l}\text { cholagogue } \\
\text { choleretic }\end{array}$ \\
\hline
\end{tabular}

TABLE II

Analysis of mutagenic activity of plant extracts in Ames test utilizing TA98 and TA100 strains of Salmonelle typhimurium with metabolization

\begin{tabular}{|c|c|c|c|c|c|c|}
\hline \multirow{2}{*}{ Samples } & & \multicolumn{2}{|c|}{ TA98 } & \multicolumn{2}{|c|}{ TA100 } & \multirow{2}{*}{$\begin{array}{l}\text { Main constituents } \\
\text { (Alice et al. 1985) }\end{array}$} \\
\hline & & Mutag. $c$ & $\mathrm{R} / \mathrm{p}^{\mathbf{d}^{d}}$ & Mutag. & $\mathrm{R} / \mathrm{pl}$ & \\
\hline Water & & - & $44 \pm 3^{e}$ & - & $149 \pm 5$ & \\
\hline Aflatoxin $^{b}$ & & + & $402 \pm 2$ & + & $439 \pm 2$ & \\
\hline A. satureoides & (f) & + & $174 \pm 3$ & + & $310 \pm 3$ & flavonoids \\
\hline 1. rhombifolia & (1) & - & $37 \pm 1$ & - & $200 \pm 2$ & flavonoids, alkaloids \\
\hline D. incanum & $\begin{array}{l}\text { (l) } \\
\text { (s) }\end{array}$ & - & $\begin{array}{l}76 \pm 1 \\
40 \pm 2\end{array}$ & - & $\begin{array}{l}147 \pm 5 \\
160 \pm 3\end{array}$ & $\begin{array}{l}\text { flavonoids, tannins, } \\
\text { saponins }\end{array}$ \\
\hline B. anomala & $\begin{array}{l}(1) \\
(s)\end{array}$ & $\begin{array}{l}+ \\
-\end{array}$ & $\begin{array}{r}186 \pm 8 \\
41 \pm 1\end{array}$ & $\begin{array}{l}- \\
-\end{array}$ & $\begin{array}{l}130 \pm 5 \\
158 \pm 2\end{array}$ & $\begin{array}{l}\text { tannins, } \\
\text { saponins }\end{array}$ \\
\hline T. asperior & $\begin{array}{l}\text { (1) } \\
\text { (s) }\end{array}$ & - & $\begin{array}{l}45 \pm 4 \\
26 \pm 7\end{array}$ & $\begin{array}{l}- \\
-\end{array}$ & $\begin{array}{l}145 \pm 4 \\
136 \pm 7\end{array}$ & $\begin{array}{l}\text { flavonoids, tannins } \\
\text { triterpenes, saponins }\end{array}$ \\
\hline L. divaricata & $\begin{array}{l}\text { (1) } \\
\text { (s) }\end{array}$ & $\begin{array}{l}+ \\
-\end{array}$ & $\begin{array}{r}141 \pm 5 \\
31 \pm 3\end{array}$ & $\begin{array}{l}- \\
-\end{array}$ & $\begin{array}{l}145 \pm 5 \\
134 \pm 3\end{array}$ & flavonoids, tannins, saponins \\
\hline M. ilicifolia & (l) & - & $48 \pm 2$ & - & $139 \pm 2$ & $\begin{array}{l}\text { flavonoids, tannins, saponins, } \\
\text { alkaloids }\end{array}$ \\
\hline
\end{tabular}

$a:$ corresponds to the negative control; $b$ : positive control $(0,5 \mu \mathrm{g} / \mathrm{plate}) ; c:+$ mutagenic; - non mutagenic; $d$ : $\mathrm{R} / \mathrm{pl}=$ revertants $\mathrm{His}^{+} /$plate; $\boldsymbol{e}: \mathrm{S} . \mathrm{D}$.

Samples of plant extracts correspond to $100 \mathrm{mg}$ of dried material/plate. 
TABLE III

Analysis of mutagenic activity of plant extracts in Ames test utilizing TA102 strain of Salmonella typhimurium with metabolization

\begin{tabular}{|c|c|c|c|}
\hline \multirow{2}{*}{ Samples } & \multicolumn{2}{|c|}{ TA102 } & \multirow{2}{*}{$\begin{array}{l}\text { Main constituents } \\
\text { (Alice et al. 1985) }\end{array}$} \\
\hline & Mutagenic ${ }^{C}$ & $\mathrm{R} / \mathrm{pl}^{d^{d}}$ & \\
\hline Water ${ }^{n}$ & - & $385 \pm 30^{e}$ & \\
\hline 2-amino-antraceno ${ }^{b}$ & + & $950 \pm 15$ & \\
\hline A. satureoides & + & $1295 \pm 10$ & flavonoids \\
\hline B. anomala & - & $426 \pm 15$ & tannins, saponins \\
\hline L. divaricata & - & $387 \pm 20$ & flavonoids, tannins, saponins \\
\hline
\end{tabular}

For definition, see footnote to Table II.

The positive extracts were tested in TA102 strain, which detects a variety of oxidative mutagens, active forms of oxygen and alkylating agents, and which has an intact excision-repair pathway (Levin et al., 1982). Positive results were obtained for $A$. satureoides extracts (Table III).

\section{DISCUSSION}

The positive results obtained in genotoxic assays for $A$. satureoides, $B$. anomala and $L$. divaricata were correlated to the presence of tannins and flavones with certain hydrexylation patterns $(5,7$ hydroxyl substitution) such as quercetin and kaempferol in these extracts. (Macgregor \& Wilson, 1988; Vargas et al., 1989, 1990). High intakes of tannins and related anthocyanins through plant materials are correlated to esophageal cancer (Morton, 1980). However some tannins have antioxidative characteristics and therefore, must work in some way as antimutagenic and anticarcinogenic agents (Kada et al., 1985).

In all assays, significant genotoxic effect was seen in the presence of microsomal activation only. Flavonols occur mainly in a pro-mutagenic form but the mutagenic activity is recovered by microsomal hydrolysis or by glycosidases. (Göggelmann \& Schimmer, 1986; Ravanel et al., 1987).

The $A$. satureoides aqueous extract contains four polyphenols: quercetin and 3-methoxyquercetin flavonols, luteolin flavone and caffeic-acid (Simões, 1984). The results in $\boldsymbol{A}$. satureoides extracts are indicative of the mutagenic activity of quercetin, 3-methoxyquercetin and caffeic acid mutagenic action (Ames, 1983; Mac Gregor, 1986; Ravanel et al., 1987; Vargas et al., 1990). The mutagenic acitivity is more intense in TA98 than TA100 strains. This is to be expected in accordance with the flavonol-like quercetin in S. typhimurium (MacGregor \& Wilson, 1988).

The positive response obtained in TA102 strain for $A$. satureoides extract can be either due to by oxidative reactions of caffeic acid and quercetin originating quinones and generating hydrogen peroxide, or by alkyiating action of quercetin metabolization products (quinone - methides) in the bacterial DNA bases. (Ames, 1983; Ravanel et al., 1987; Vargas et al., 1990). The response obtained for this strain in $L$. divaricata and $B$. anomala aqueous extracts where tannins are present (Kada et al., 1985) was negative.

The $A$. satureoides extract was also analyzed in SOS spot chromotest (Quillardet \& Hofnung, $1985)$ and Microscreen phage-induction assay (Rossman et al., 1984). These assays (Vargas et al., 1990) confirm the presence of genotoxicity of the $A$. satureoides extracts showing its capacity to induce prophage and/or SOS response. Positive SOS response in PQ230 strain which detects alkylating agents reinforces the hypothesis of the same action form as detected in the Ames test (Hofnung \& Quillardet, 1986).

These studies show that high priority should be given to the evaluation of the potential risks to human health represented by the indiscriminate use of extracts of these plants. 


\section{ACKNOWLEDGEMENTS}

To C. B. Alice for the plants selection and classification, and to Dr Eloy Julius Garcia for assistance in preparing the English version of the manuscript.

\section{REFERENCES}

ALICE, C. B.; SILVA, G. A. A. B.; SIQUEIRA, N. C. S. \& MENTZ, L. A., 1985. Levantamento fitoquímico de alguns vegetais utilizados na medicina popular do Rio Grande do Sul (Parte 1). Cad. Farm., 1: 83-94.

AMES, B. N., 1983. Dietary carcinogens and anticarcinogens. Science, 221: 1256-1264.

BROWN, J. P., 1980. A review of the genetic effects of naturally occuring flavonoids, anthraquinones and related compounds. Mutat. Res., 75: 243-277.

GOGGELMANN, W. \& SCHIMMER, O., 1986. Mutagenic activity of phytotherapeutical drugs. Prog. Clin. Biol. Res., 206: 63-72.

HOFNUNG, M. \& QUILLARDET, P., 1986. Recent developments in bacterial short term tests for the detection of genotoxic agents. Mutagenesis, 1: 319-330.

KADA, T.; KANEKO, K.; MATSUZAKI, S.; MATSUSAKI, T. \& HARA, Y., 1985. Detection and chemical identification of natural bio-antimutagens. Mutat. Res, 150:127-132.

LEVIN, D. E.; HOLLSTEIN, M.; CHRISTMANN, F.; SCHWIERS, E. A. \& AMES, B. N., 1982. A new Salmonella tester strain (TA102) with A. T. base pairs at the site of mutation detects oxidative mutagens, Proc. Natl Acad. Sci., 79: 7445-7449.
MACGREGOR, J. T., 1986. Genetic toxicology of dietary flavonoids, p. 33-43. In I. Knudsen, Genetic toxicology of the diet. Alan R. Liss. New York.

MACGREGOR, J. T. \& WILSON, R. E., 1988. Flavone nutagenicity in Salmonella typhimurium: dependence on the pKM101 plasmid and excision-repair deficiency. Environm Mol. Mutag., 11:315-322.

MARON, D. M. \& AMES, B. N., 1983. Revised methods for the Salmonella mutagenicity test. Mutat. Res., 113: 173-215.

MORTON, J. F., 1980. Search for carcinogenic principles, p. 53-73. In T. Smainand \& R. Kleiman (eds.), Recent Advances in Phytochemistry, Vol. 14, Plenum, New York.

QUILLARDET, P. \& HOFNUNG, M., 1985. The SOS Chromotest, a colorimetric bacterial assay for genotoxins: procedures. Mutat. Res., 147:65-78.

RAVANEL, P.; LECLERQ, M. \& MARIOTTE, A. M., 1987. La genotoxité des flavonoides. Plantes Méd. Phytotér., XXI: 63-78.

ROSSMAN, T. G.; MOLINA, M. \& MEYER, L. W, 1984. The genetic toxicology of metal compounds: I. Induction of Prophage in $E$, coli WP2. $(\lambda)$. Environm. Mutag., 6:59-69.

SIMŌES, C. M., 1984. Investigaçāo química farmacológica de Achyrocline satureoides (Lam) D. C., Compositae ("Marcela"). Master Thesis, UFRGS, $186 \mathrm{p}$.

VARGAS, V. M. F.; MOTTA, V. E. P.; ALICE, C. B.; GUIDOBONO, R. R. \& HENRIQUES, J. A. P., 1989. Mutagenic activity of plant extracts used in popular medicine. Rev. Bras. Farm., 70:65-67.

VARGAS, V. M. F.; MOTTA, V. E. P.; LEITÃO, A. C. \& HENRIQUES, J. A. P., 1990. Mutagenic and genotoxic effects of aqueous extracts of Achyro. cline satureoides in prokariotic organisms. Mutat. Res., 240: 13-18. 